\title{
Service Quality Perception and Customer Satisfaction in Islamic Banks of Oman
}

\author{
Naushad ALAM ${ }^{1}$, Hanin Abdulrhman AL-AMRI ${ }^{2}$
}

Received: July 03, 2020 Revised: July 25, 2020 Accepted: August 10, 2020

\begin{abstract}
Service quality of any institution is a pull factor for attracting and retaining the customer. The present study examines the customer satisfaction level toward the quality of service offered by the Islamic banks in Oman. It also aims to find out which dimension influences customer satisfaction more concerning the other dimension chosen for the study. To fulfil the need of the study, a structured questionnaire is distributed amongst 100 customers of Islamic banks. The random stratified sampling technique is used for the collection of the data. The collected data is analyzed using the correlation and the multiple linear regression techniques. The result of the study indicates that timely service provided by the banking personnel has a mean score of 4.57, bank staff readiness to serve the customer has a mean score of 4.36 , and the security of the banking operation has a mean score of 4.37 occupies the highest rank in their respective dimension chosen for the study. The study reveals that all three dimensions of quality of service represented by Services Reliability, Services Responsiveness and Services Security have a positive and significant correlation with customer satisfaction. The regression results also indicate that all three dimensions influence customer satisfaction of the Islamic banks.
\end{abstract}

Keywords: Islamic Banking, Service Quality, Customer Satisfaction, Service Dimension

JEL Classification Code: G21, C30, L80

\section{Introduction}

In the last four decades, the establishment of Islamic banks has increased, spread globally, and has been accepted by all, cutting across regions and religions. This spread is attributed to Islamic banks following Islamic principles known as shariah and having products with no element of uncertainty as compared to the conventional financial system. It gained prominence post-financial crisis and is playing a pivotal role in the economic growth (Tabash \& Dhankar, 2014).

${ }^{1}$ First Author and Corresponding Author. Assistant Professor, Department of Finance and Economics, College of Commerce and Business Administration, Dhofar University, Sultanate of Oman [Postal Address: P. O. Box 2509, Salalah, 211, Sultanate of Oman] Email: nalam@du.edu.om

${ }^{2}$ College of Commerce and Business Administration, Dhofar University, Sultanate of Oman. Email: H201500165@du.edu.om

(c) Copyright: The Author(s)

This is an Open Access article distributed under the terms of the Creative Commons Attribution Non-Commercial License (https://creativecommons.org/licenses/by-nc/4.0/) which permits unrestricted non-commercial use, distribution, and reproduction in any medium, provided the original work is properly cited.
Islamic banks are no longer business institutions that cater to the need of Muslim only (Khan , Amine, Uddin, \& Zaman, 2011). However, they have become competitive institutions, side by side with conventional banks, in an attempt to acquire new clients and to retain them and have grown over the years (Aggarwal \& Yousef, 2000). Islamic banks build their competitive position by emphasising the quality of their services, which will improve their customer satisfaction and increase their loyalty (Amin, Isa, \& Fontaine, 2013). They need to continue to work in a particularly competitive way with their international counterparts by providing offers of high-quality products and services. Unlike conventional banks, Islamic banks operate following the precepts of the sharia and its rules in pursuit of economic development. It is based on the application of the principles of profit and risk sharing (Alnaser, Ghani, \& Rahi, 2018).

Earlier studies focused on different aspects of the quality of the banking service in terms of its concepts, limitations, and methods of operation. The present study is to find the quality of the banking service in Islamic banks operating in the Dhofar region, Oman to determine the impact of perceived quality of Islamic banking services on the satisfaction of 
their customers. The importance of the study lies in its being one of the few studies that examine the quality of service and its role in customer satisfaction in Islamic banking activity in Oman. This study will also help managers in Islamic banks to identify services that influence customer satisfaction and to take proactive measures to meet the needs of the customer, to win their trust and their loyalty towards banks.

\section{Literature Review}

\subsection{Service Quality Perception}

Alamgir and Shamsuddoha (2003) defined Service Quality as the difference between the present service performance and their anticipations. Based on their study, they suggested service dimensions which can be adopted for higher growth and retain the customer. They also highlighted how the understanding of service dimension is vital for sustainable growth and for meeting customer expectations. Ahmad and Haron (2002) found that the cost of financing leads to either positive or negative perception of Islamic product and services. People responsible for the financial affair of the company get more attracted toward the Islamic products and services if the cost is lower compared to the conventional counterparts. Jiang and Wang (2006) defined perceived service quality as the customer's assessment of the performance of the derived pleasure in good sense and the arousal, on the other hand, influence the quality of service as recognised in the hedonistic sense.

Tran (2020) investigated the interaction between the service quality, experience value and intention of behaviour and quality relationships. He found that service quality influences the purchase intention, together with the experience values and relationship quality. Ali and Raza (2015) studied how the customer is satisfied with the quality of service provided using the modified SERVQUAL model. Based on their findings, they concluded that the service quality multidimensional scale is positively and significantly related to the customer satisfaction unidimensional scale. The study further throws insight into understanding the behavioral traits of the Islamic bank customer. The study also finds that customers of Islamic banks are happy because these banks are complying with the shariah principles. Baber (2019) uses the modified e-SERVQUAL model to examine the perception of Islamic bank customer toward Islamic banking. It confirmed that ease of the usage of services, shariah compliance, trust and security have a positive and significant association with the performance of the Islamic bank.

\subsection{Service Quality and Customer Satisfaction}

Tabish, Albugami, Salim, and Akhtar (2019) found reliability, responsiveness to customers demand, ease of usage together with privacy and security leading to higher customer satisfaction. The study also highlighted that accessibility, despite being statistically insignificant, has a positive relationship with customer satisfaction. Anwar and Goso (2016) examined the quality of service using five dimensions - tangible, empathy, reliability, responsiveness, and assurance. They concluded that quality of service and customer handling lead to higher customer satisfaction and influence customer loyalty toward the bank. Saad (2012) made a comparative study between the Islamic bank and the conventional bank and found that customer satisfaction is the outcome of quality of service provided it includes ability, friendliness towards the client, and the level of efficiency in execution of the banking transaction. To retain its customers, the Islamic bank is found to need to improve the quality of services and the physical space for the customer.

Rehman (2012) explored the correlation between customer satisfaction and dimensions of service quality among Islamic banks in Pakistan, UK and UAE. The results of the study revealed that UAE Islamic banking customers suggested that tangible and assurance represent significant dimensions of customers satisfaction. In contrast, the UK and Pakistani Islamic banking customers consider reliability, empathy and assurance as significant indicators to satisfy their needs. Usman (2015) finds that it is the trust of a customer toward their respective banks. To examine the trust of clients with their respective banks, three groups of customers were identified, those belonging to the Islamic bank, to the conventional bank, and to both types. The study revealed that the trust was more significant for the Islamic bank. It is also expressed by those who are not a customer of the Islamic bank. The attraction of the customer toward the Islamic bank is mostly due to trust.

Estiri, Hosseini, Yazdani, and Nejad (2011) examined customer satisfaction of Islamic banks in Iran. The findings indicate that service quality is positively related to customer satisfaction and empathy; service quality has the highest impact, followed by other components like responsiveness, assurance and intangibles. Janahi and Almubarak (2017) used the CARTER model to investigate the relationship between the quality of service, comprising six dimensions, and the level of customer satisfaction in Bahrain. The results of the study indicate positive relationships amongst the chosen factors and customer satisfaction.

\section{Research Methodology}

The assessment of the customer satisfaction of Islamic banking requires to collect the opinions of customers. The researcher utilised a survey model based on a structured questionnaire to collect these data. The stratified random 
sampling is used for the collection of data among Islamic banking customers. To accomplish the analysis of the collected data from Islamic banking customers, the researcher adopted both (1) Correlation analysis, to measure the correlation between the quality of service and customers' satisfaction, and (2) Multiple Regression analysis, to find the customers' satisfaction as the dependent variable influenced by the different dimension of quality of service represented by Services Reliability, Services Responsiveness and Services Security.

\subsection{Research Hypotheses}

The study covers the Islamic banking sector in the Dhofar region of Sultanate of Oman. One hundred customers of Omani Islamic banks are selected randomly for the need of the study. The data is collected through a questionnaire distributed to the Islamic bank customers.

H1: Services reliability has a significant effect on customers 'satisfaction of Omani Islamic banking.

H2: Services responsiveness has a significant effect on customers' satisfaction of Omani Islamic banking.

H3: Services security has a significant effect on customers 'satisfaction of Omani Islamic banking.

H4: Service quality offered by Omani Islamic banks has a significant effect on their customers'satisfaction.

\section{Results}

The measurement of the customers' satisfaction toward the services offered by the Islamic banking sector in Oman is studied using three dimensions related to the quality of services, namely, Services Reliability, Services Responsiveness, and Services Security; these dimensions are used as independent variables, whereas the Customer Satisfaction is the unique dependent variable. The effect of the offered quality of services on customer satisfaction is examined by the correlation and regression analysis. Table 1 shows the basic information of the study, which includes respondent profile and the Islamic banks for the study.

Table 1 indicates that females represent $42 \%$ of the sample, whereas males constitute $58 \%$. Customers with secondary education level account for $23 \%$ of respondents, customers with a diploma degree represent $56 \%$ and customers with a Bachelor degree represent 12\%; nine percent of respondents have a Master degree or above. Table 1 shows that Alizz Islamic Bank customers represent 36\% of the sample, the customers of Maisarah Islamic Bank represent 30\% and customers of Al Muzn Islamic Bank and Bank Nizwa represent $10 \%$ and 24\%, respectively. Table 2 shows the descriptive analysis.
As shown in Table 2 in the descriptive statistics of the first independent variable, service reliability item (3) comes in the first place with Mean=4.57 and Std. Deviation $(\mathrm{SD})=0.685$, this item indicates that the bank's staff gives services at the favourable time. This is similar to the findings by (Othman \& Owen, 2001). In the second position is the item (1), which comes with Mean=4.40 and $\mathrm{SD}=0.550$. In third position is for item (4) where the Mean=2.74. The Fourth rank is registered for the second item where its Mean= 2.71 and $\mathrm{SD}=1.20$.

The second independent variable Service Responsiveness in Table 2 shows that item (7) occupies the first rank with Mean $=4.36$ and $\mathrm{SD}=0.578$. This item states that staff in banks are always ready to serve customers. The second rank is for item (8) with Mean=4.22. The third rank is item (6) with Mean= 4.19 and $\mathrm{SD}=0.545$. The fourth position is for item (5) with Mean=4.00.

The third independent variable, Service Security, in Table 2 shows that item (9) occupies the first place with Mean $=4.37$ and $\mathrm{SD}=0.646$, this item indicates that banking operations were secured. The second position is for item (11) with Mean= 4.36. The third position is for item (10) with Mean=4.21 and $\mathrm{SD}=0.518$. The fourth position is for item (12) with Mean=4.17.

Finally, the descriptive statistics related to the dependent variable, Customer Satisfaction, shows that item (13) is in the first position, with Mean $=4.57$ and $\mathrm{SD}=0.685$ and it indicates that customers are satisfied with the Islamic banking financial services. The second position is for item (16) with Mean=4.19. The third position is for item (15) with Mean $=4.00$ and $\mathrm{SD}=0.921$. The last position is for item (14) with Mean=2.74.

Table 1: Basic Information

\begin{tabular}{|l|c|c|}
\hline Demographic statistics & Frequency & Percent (\%) \\
\hline Gender & 58 & 58 \\
\hline Male & 42 & 42 \\
\hline Female & 23 & 23 \\
\hline Education & 56 & 56 \\
\hline Secondary & 12 & 12 \\
\hline Diploma & 19 & 19 \\
\hline Bachelor & & \\
\hline Master or Above & 36 & 36 \\
\hline The Bank & 30 & 30 \\
\hline Alizz Islamic Bank & 10 & 10 \\
\hline Maisarah Islamic Bank & 24 & 24 \\
\hline Al Muzn Islamic Bank & & \\
\hline Bank Nizwa &
\end{tabular}


Table 2: Descriptive Analysis

\begin{tabular}{|c|c|c|c|c|}
\hline \multicolumn{2}{|c|}{ Services Reliability } & \multirow{2}{*}{$\begin{array}{c}\text { Rank } \\
2\end{array}$} & \multirow{2}{*}{\begin{tabular}{c|} 
Mean \\
4.4
\end{tabular}} & \multirow{2}{*}{$\frac{\text { Std. Deviation }}{0.55}$} \\
\hline 1 & The bank keeps its records accurately & & & \\
\hline 2 & The bank provides a large range of banking services & 4 & 2.71 & 1.209 \\
\hline 3 & The bank's staff give services at the favourable time & 1 & 4.57 & 0.685 \\
\hline 4 & The bank featured by speed and efficiency of its transactions & 3 & 2.74 & 1.134 \\
\hline \multicolumn{5}{|c|}{ Services Responsiveness } \\
\hline 5 & The bank has more branches in Dhofar region, Oman & 4 & 4 & 0.921 \\
\hline 6 & In the bank, counter services are fast and efficient & 3 & 4.19 & 0.545 \\
\hline 7 & The bank's staff are always ready to serve customers & 1 & 4.36 & 0.578 \\
\hline 8 & The rate of responding to a customer request is high & 2 & 4.22 & 0.645 \\
\hline \multicolumn{5}{|c|}{ Services Security } \\
\hline 9 & My banking operations were secured & 1 & 4.37 & 0.646 \\
\hline 10 & $\begin{array}{l}\text { My bank informs me of each operation processed on my } \\
\text { account }\end{array}$ & 3 & 4.21 & 0.518 \\
\hline 11 & $\begin{array}{l}\text { Each external online operation do not process except with my } \\
\text { approval (Via SMS code) }\end{array}$ & 2 & 4.36 & 0.41 \\
\hline 12 & The bank provides confidentiality to customers' data & 4 & 4.17 & 0.514 \\
\hline \multicolumn{5}{|c|}{ Customer Satisfaction } \\
\hline 13 & I am satisfied to the Islamic banking financial services & 1 & 4.57 & 0.685 \\
\hline 14 & $\begin{array}{l}\text { I am satisfied with services and products provided by my } \\
\text { Islamic bank }\end{array}$ & 4 & 2.74 & 1.134 \\
\hline 15 & I am satisfied with employees respond & 3 & 4 & 0.921 \\
\hline 16 & I don't think to leave my bank & 2 & 4.19 & 0.545 \\
\hline
\end{tabular}

Table 3: Pearson's Correlation of Coefficient

\begin{tabular}{|l|c|c|c|}
\hline Service Dimension & Pearson Correlation & Sig. (2-tailed) & N \\
\hline Service Reliability & 0.742 & 0 & 100 \\
\hline Service Responsiveness & 0.565 & 0 & 100 \\
\hline Service Security & 0.435 & 0 & 100 \\
\hline
\end{tabular}

Table 3 shows the relationships between the dimensions chosen as factors influencing customer satisfaction. Table 3 show that the Services Reliability and Customer Satisfaction have a strong positive and significant relationship. The correlation test between Services Responsiveness and Customer Satisfaction proves, as shown in Table 3, that the Pearson Correlation is $56.5 \%$, which indicates a significant correlation at the 0.01 level. The third correlation test shows that the $\mathrm{P}$-value $=0.000$ and the Pearson correlation is $43.5 \%$. This indicates that there is a significant correlation between Services Security and Customers Satisfaction. Thus, based on the results obtained in Table 3 , it can be said that the three dimensions chosen for the study have got significant relationships with customer satisfaction, the dependent variable.

The results of the multiple linear regression analysis, as shown in Table 4, indicates the service dimensions represented by service reliability, service responsiveness, and service security influence customer satisfaction. The obtained F-value in Table 4 is 185.847 , and the corresponding $\mathrm{p}$-value is 0.000 , indicating that the predictors variables influence the dependent variable. This result is similar to the findings by Hamzah, Ishak, and Mohd Nor (2015) and Faisal, Shabbir, Javed, and Shabbir (2016). 
Table 4: Regression output

\begin{tabular}{|l|c|c|c|c|c|}
\hline & Sum of Square & df & Mean Square & F & Sig. \\
\hline Regression & 17.222 & 3 & 5.741 & 185.847 & 0.000 \\
\hline Residual & 2.965 & 96 & 0.031 & & \\
\hline Total & 20.187 & 99 & & & \\
\hline
\end{tabular}

a. Predictors: (constant) Service Reliability, Service Responsiveness, Service Security

b. Dependent Variables: Customer satisfaction

\section{Conclusion and Recommendations}

The banking industry is service-oriented, and the retention of customers depends upon the quality of service offered. Customer satisfaction will determine loyalty (Kitapci, Dortyol, Yaman, \& Gulmez, 2013; Kashif, Wan Shukran, Rehman, \& Sarifuddin , 2015). The result of the study indicate that the Islamic bank customer is overall satisfied by the services offered by the Islamic bank. The study highlighted that all the dimensions chosen have positive and significant relationships with customer satisfaction. The study also revealed that front desk officer are not well versed with the shariah principles. At present, Islamic banks in Oman have around $14 \%$ of the total banking share. This can be increased by developing innovative shariah-compliant products to attract customer and reduce the risk of banking by choosing advanced technology. The study has limitations in that only four banks are included in the analysis; more banks should be included to have better results and understanding of the customer needs.

\section{References}

Aggarwal, R. K., \& Yousef, T. (2000). Islamic Banks and Investment Financing. Journal of Money, Credit and Banking, 32(1), 93-120.

Ahmad, N., \& Haron, S. (2002). Perception of Malaysian corporate customertowards Islamic Banks product and service. International Journal of Islamic Financial Services, 3(4), 1-16.

Alamgir, M., \& Shamsuddoha, M. (2003). Service Quality Dimensions: A Conceptual Analysis. The Chittagong University Journal of Business Administration, 19(2004), 1-11.

Ali, M., \& Raza, S. A. (2015). Service quality perception and customer satisfaction in Islamic banks of Pakistan : the modified SERVQUAL model. Total Quality Management \& Business Excellence, 28(5-6), 1-19.

Alnaser, F. M., Ghani, M. A., \& Rahi, S. (2018). Service quality in Islamic banks: The role of PAKSERV model, customer satisfaction and customer loyalty. Accounting, 4(2), 63-72.

Amin, M., Isa, Z., \& Fontaine, R. (2013). Islamic banks Contrasting the drivers of customer satisfaction on image, trust, and loyalty of Muslim and non-Muslim customers in Malaysia. International Journal of Bank Marketing, 31(2), 79-97.
Anwar, S. M., \& Goso. (2016). Effect of Dimensions of Service Quality Satisfaction and Customer Loyalty of Islamic Bank in the Perspective of Islam in Palopo. Journal of Education and Vocational Research, 7(3), 48-52.

Baber, H. (2019). E-SERVQUAL and Its Impact on the Performance of Islamic Banks in Malaysia from the Customer's Perspective. Journal of Asian Finance, Economics and Business, 6(1), 169-175. https://doi.org/10.13106/jafeb.2019.vol6.no1.169

Estiri, M., Hosseini, F., Yazdani, H., \& Nejad, H. J. (2011). Determinants of customer satisfaction in Islamic banking: evidence from Iran. International Journal of Islamic and Middle Eastern Finance and Management, 4(4), 295-307.

Faisal, M., Shabbir, M. S., Javed, S., \& Shabbir, M. F. (2016). Measuring Service Quality and Customer Satisfaction in Pakistan: Evidence Based on Carter Model. International Business Management, 10(20), 5011-5016.

Hamzah, N., Ishak, N. M., \& Mohd Nor, N. I. (2015). Customer Satisfactions on Islamic Banking System. Journal of Economics, Business and Management, 3(1), 140-144.

Janahi, M. A., \& Almubarak, M. (2017). The impact of customer service quality on customer satisfaction in Islamic banking. Journal of Islamic Marketing, 8(4), 595-604.

Jiang, Y., \& Wang, C. L. (2006). The impact of affect on service quality and satisfaction:the moderation of service contexts. Journal of Services Marketing, 20(4), 211-218.

Kashif, M., Wan Shukran, S. S., Rehman, M. A., \& Sarifuddin, S. (2015). Customer satisfaction and loyalty in Malaysian Islamic banks:a PAKSERV investigation. International Journal of Bank Marketing, 33(1), 23-40.

Khan, G. M., Amine, L. S., Uddin, S. J., \& Zaman, M. (2011). The Internationalisation of Arab Bank:The Case of Ahli United Bank of Bahrain. Thunderbird International Business Review, 53(5), 581-600.

Kitapci, O., Dortyol, I. T., Yaman, Z., \& Gulmez, M. (2013). The paths from service quality dimensions to customer loyalty: An application on supermarket customers. Management Research Review, 36(3), 239-255.

Othman, A., \& Owen, L. (2001). Adopting and measuring customer service quality (SQ) in Islamic Banks: A case stiudy in Kuwait finance house. International Journal of Islamic Financial Services, 3(1), 33-47.

Rehman , A. A. (2012). Customer satisfaction and service quality in Islamic banking: A comparative study in Pakistan, United 
Arab Emirates and United Kingdom. Qualitative Research in Financial Markets, 4(2/3), 165-175.

Saad, N. M. (2012). Comparative Analysis of Customer Satisfaction on Islamic and Conventional Banks in Malaysia. Asian Social Science, 8(1), 73-80.

Tabash, M. I., \& Dhankar, R. S. (2014). The Flow of Islamic Finance and Economic Growth: an Empirical Evidence of Middle East. Journal of Finance and Accounting, 2(1), 11-19.

Tabish, M. I., Albugami, M. A., Salim, M., \& Akhtar, A. (2019). Service Quality Dimensions of e retailing of Islamic Banks and its Impact on Customer Satisfaction: An Emperical
Investigation of Kingdom of Saudi Arabia. Journal of Asian Finance, Economics and Business, 6(3), 225-234. https://doi. org/10.13106/jafeb.2019.vol6.no3.225

Tran, V. D. (2020). Assessing the Effects of Service Quality, Experience Value, Relationship Quality on Behavioral Intentions. Journal of Asian Finance, Economics and Business, 7(3), 167-175. https://doi.org/10.13106/jafeb.2020.vol7. no3.167

Usman, H. (2015). Customers Trust on Islamic Banks in Indonesia. Journal of Asian Finance, Economics and Business, 2(1), 5-13. https://doi.org/10.13106/jafeb.2015.vol2.no1.5. 